\title{
Implementing strategy by finding the non-fit: The cognition of bid opportunity screening
}

Stingl, Verena; Schriewersmann, Maximilian ; Geraldi, Joana

\section{Published in:}

Academy of Management Proceedings

Link to article, DOI:

10.5465/AMBPP.2018.14101abstract

Publication date:

2018

Document Version

Peer reviewed version

Link back to DTU Orbit

Citation (APA):

Stingl, V., Schriewersmann, M., \& Geraldi, J. (2018). Implementing strategy by finding the non-fit: The cognition of bid opportunity screening. In Academy of Management Proceedings (Vol. 2018)

https://doi.org/10.5465/AMBPP.2018.14101abstract

\section{General rights}

Copyright and moral rights for the publications made accessible in the public portal are retained by the authors and/or other copyright owners and it is a condition of accessing publications that users recognise and abide by the legal requirements associated with these rights.

- Users may download and print one copy of any publication from the public portal for the purpose of private study or research.

- You may not further distribute the material or use it for any profit-making activity or commercial gain

- You may freely distribute the URL identifying the publication in the public portal 


\title{
Implementing strategy by finding the non-fit: The cognition of bid opportunity screening
}

\author{
Verena Stingl, Joana Geraldi, Maximilian Schriewersmann \\ Accepted for presentation at the Annual Meeting of the Academy of Management, August 10- \\ 14, Chicago, IL, USA.
}

\begin{abstract}
While the screening and selection of business opportunities is critical to any venture, we know only little of the cognitive processes that guide this screening step. Through a novel approach, applying a qualitative methodology against the theoretical framework of simple heuristics, we explore the cognitive strategies of senior managers when screening opportunities to participate in competitive biddings. Our findings illustrate the adaptive selection of individual cognitive strategies, corroborating previous propositions from laboratory studies on the relationship between decision context and selection of cognitive strategies. The observed preference for cognitive strategies that relied on abstract, non-compensatory and risk-oriented cues contrasts prior findings on holistic, benefit-oriented opportunity screening in entrepreneurial settings. These differences trace back to the particular context of our case, concerning feedback modes and decision criteria, which are shaped by organizational behaviour and sensemaking.
\end{abstract}

\section{Keywords}

Behavioral decision research; Cognitive Schema, Scripts, Mental Models/Maps; Qualitative (case study, content analysis, interview, narratives...); Simple Heuristics; Opportunity Screening 